\title{
Мартин Кратохвил*
}

ПФ УКФ, Нитра, Словакия

\section{ЗНАЧЕНИЕ СЕРИЙНОСТИ И ПОВТОРЕНИЯ МУЗЫКАЛЬНОГО И ХУДОЖЕСТВЕННОГО ВЫРАЖЕНИЯ В ПЕДАГОГИЧЕСКОЙ СРЕДЕ}

Резюме: В статье отражены некоторые аспекты повторения как феномена, возникающего в процессе создания музыки и объектов изобразительного искусства.

На фоне подготовки и создания выставки художественных работ студентов педагогического факультета Университета Константина Философа в Нитре автор анализирует аспекты творчества, в котором использовано явление повторения как основной принцип. Размышления указывают на междисциплинарное взаимодействие изобразительного и музыкального творчества.

Ключевые слова: серия, повтор, узор, ритм, шаблон.

\section{ВВЕДЕНИЕ}

Серийность и повторение присутствуют во всех проявлениях нашей повседневной жизни. Говоря об этом принципе, можно также употреблять слова последовательность и периодичность. Серийное расположение составляет важную часть структурирования и регулирования материальных и нематериальных жизненных процессов. Структура пространственновременного расположения предметов и явлений относительно друг друга, их последующее, но постоянно повторяющееся движение является частью нашего мышления, системы коммуникации, поведения, а также производственных процессов или экономических законов во время их процветания или кризиса.

В педагогической среде принцип повторения ассоциируется с матерью учения и мудрости («Repetitio est mater studiorum»). Повторение - это один из принципов обучения, но также это и способ созидания. По принципу повторения мир строится и формируется. Этот принцип наблюдаем в

\footnotetext{
*mkratochvil@ukf.sk

** Статья создана при поддержке проекта KEGA 003UK-4/2020.
} 
Кратохвил, М.: Значение серийности и повторения музыкального и...

ЗБОРНИК РАДОВА • ГОД. 24 • БР. 23 • ДЕЦЕМБАР 2021 • 187-206

элементарных ДНК и в построении или поддержании межличностных отношений. Этот принцип может быть и позитивным, и негативным. Он позитивный с точки зрения обучения способом повторения и приумножения уже известного. Негативный - при бездумном принятии шаблонов - «идолов театра, площадей и пещер», - так их сформулировал английский философ Фрэнсис Бэкон в начале 17 века. Или, говоря современным языком, плагиат, стереотип, предрассудки и предубеждения. В некотором смысле повторение это общее правило существования. В принципе повторение известного продвигает вещи и явления в развитии. Мы повторяем что-либо, чтобы понять уже существующие принципы и найти новые возможности. Механическое же повторение без развития через некоторое время перестает представлять какойлибо интерес. Мы начнем или что-то добавлять в этот процесс (приукрашать, конкретизировать) или, наоборот, убавлять (редуцировать, упрощать, абстрагировать). Мера добавления или упрощения определяет: развиваем ли мы что-либо или ухудшаем. Этот показатель становится решающим при оценке добавочной стоимости процесса и преимуществ внесения изменений в известное и повторяемое. Точно так же мы создаем ценности на личном и на социальном уровне жизни.

Мы продемонстрируем принцип повторения на основании серий и повторений, приведём конкретные примеры из педагогической практики.

\section{СЕРИЯ}

С этимологической точки зрения это слово происходит от латинского «seriés», означающего цепь, ряд, последовательность, расположение, и от латинского «serere» соединять - строить в ряд (Králik, 2015). Таким образом, это определенное количество вещей или явлений, упорядоченных в серию или цепочку с пространственно-временными интервалами в структуре взаимоотношений и последовательностей. Последовательное расположение создается не только путем повторения определенных элементов, но также путем их варьирования, комбинирования и перестановки.

В области изобразительного искусства мы встречаем три основных типа серийных структур (Rusínová, 2017). Первая - в виде открытой системы. Это свободное повторение и взаимосвязь отдельных образов, объектов, персонажей или мотивов. В этом контексте в изобразительном искусстве мы встречаем термин «цикл». Это авторские циклы - серия обработки определенной темы путем варьирования ее содержания, смысла или формальных решений. Примером может служить серия картин Руанского собора Клода Моне (Claude Monet), на которых запечатлен фасад собора в разное время суток и времени года и отражены изменения его внешнего вида при различных условиях освещения. Этот цикл можно назвать серией работ о 
Кратохвил, М.: Значение серийности и повторения музыкального и... ЗБОРНИК РАДОВА • ГОД. 24 • БР. 23 • ДЕЦЕМБАР 2021 • 187-206

свете, соборе, материи и нематериальном. В этой серии рассказывается о влиянии света на восприятие твердой конструкции собора, о визуальных явлениях и метаморфозах цвета, которые демонстрировались на его поверхности (Рис. 25-62).
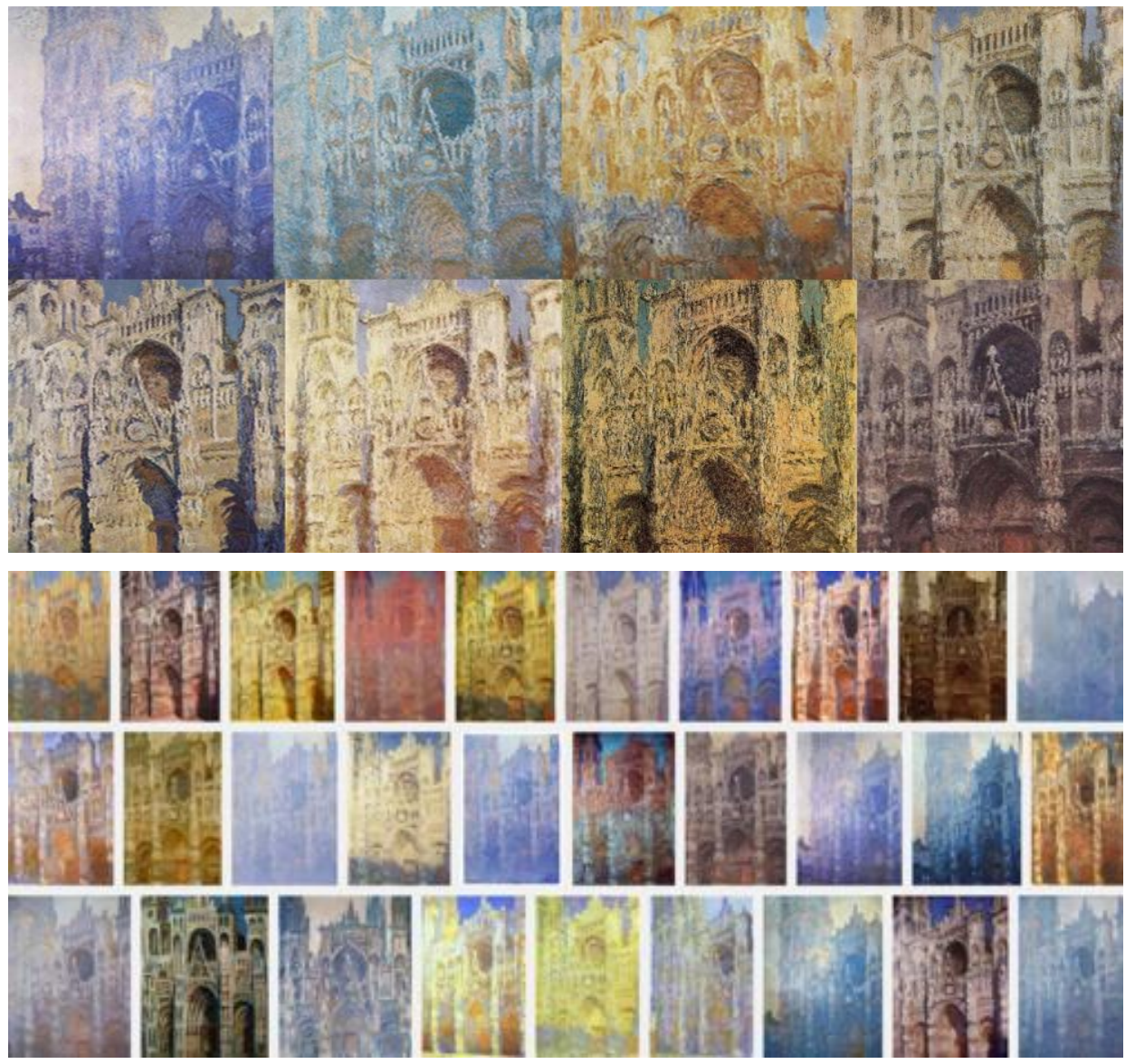

Рис. 25-62 Образец Руанского собора Клода Моне, холст, масло. Каждый приблизительно 107 х 73 см 1892 - 1894 г.

Доступно онлайн: https://fahrenheitmagazine.com/arte/un-paseo-por-la-serie-de-lacatedral-de-rouen-de-monet

Другой пример - живописные композиции Пита Мондриана (Piet Mondrian), основанные на вариациях формальных решений геометрической абстракции, где автор на асимметричной сетке по горизонтали и вертикали определяет области, иногда заполняя их чистым цветовым тоном. 
Кратохвил, М.: Значение серийности и повторения музыкального и... ЗБОРНИК РАДОВА • ГОД. 24 • БР. 23 • ДЕЦЕМБАР 2021 • 187-206

Второй тип серии можно охарактеризовать как заранее заданную концепцию целостности произведения, основанную на ритмическом повторении одинаковых элементов через определенные промежутки времени. Этот тип серий можно продемонстрировать в работе Милоша Урбасека (Miloš Urbasek) (Рис. 23-24).
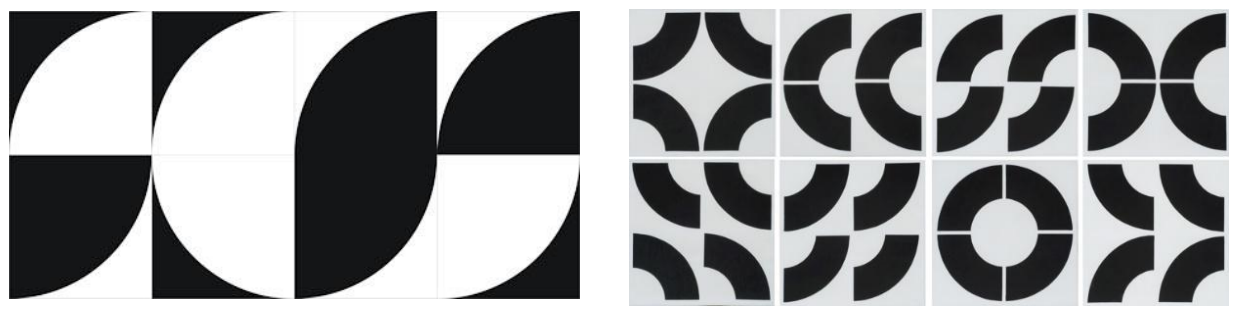

Рис. 23-24 Милош Урбасек: Серия O, 1967, 8 шт., сериграфия, $20 \times 20$ см / серия Circle elements. Variation 5 from 81969 2, polystyrol, 194 x 388 cм.

Доступно онлайн: https://www.sypka.cz/32-aukce-vytvarneho-umeni-starozitnostia-designu/a60/d13945/\#!prettyPhoto/0/ http://urbasek.com/index-cs.html

В циклах «Шифры и криптографические машины» (1965) определенно был соблюден принцип серийной композиции, который он позже развил в графике и живописи, начиная с 1966 года. Урбасек сочетает (нео)конструктивный синтаксис с элементами шрифтового характера. Способы, которые он использовал - этапирование, сортировка фрагментов, постепенное увеличение или исчезновение и т. д. - оказались эстетически очень эффективными. По словам Иржи Валоха (Jiří Valoch), работа Милоша Урбасека (Miloš Urbasek) является одним из лучших достижений чехословацкого искусства своего времени.

Анализ буквы О, преобразованной в круг и его части, он выполнил в монохромной и цветной сериях, позволяя любую композицию произведений превращаться в ритмические динамические поверхности. Темой картин Урбасека стал изолированная графема, подвергнутая определенной визуальной операции, которую он собрал в более крупные синтаксические структуры, например, в серии O-V. Урбасек использовал созданные им шаблоны в своих картинах. Благодаря им он смог использовать эстетическую специализацию неэстетического аспекта цветового следа, случайно возникшего во время манипуляции с шаблоном. Его путь от графемы О (мы не знаем, буква ли это О или цифра 0) трансформировалась в форму круга. Разделив его осью, он получил элементы, которые можно было объединить в различные комбинации (1968). Милош Урбасек абсолютизирует точные правила композиции и возможность комбинаторных связей между живописными элементами как эстетическое сообщение (Valoch, 2020). 
Кратохвил, М.: Значение серийности и повторения музыкального и...

ЗБОРНИК РАДОВА • ГОД. 24 • БР. 23 • ДЕЦЕМБАР 2021 • 187-206

Третий тип серий стоит на границе первого (открытая структура) и второго (закрытая структура) и представляет серию как последовательное повествование. Его цель - разработать историю, обусловленную временем и пространством, основанную на повторении основных объектов, персонажей, подмотивов. Примерами могут быть иллюстрации к отдельным рассказам или комиксы.

В разных музыкальных формах присутствуют разнообразные повторения. Нам встречаются такие понятиями, как повтор, остинато, рифф, припев и т. д. Музыка исторически понимается как преимущественно темпоральный тип искусства, а повторение в музыке привязано к категории времени. С общей точки зрения время можно разделить на циклическое и линейное. Циклическое время характерно для природных процессов, которые задаются вращением Земли по своей орбите вокруг Солнца. А линейное время характерно для культурных конструктов измерения времени - час, день, год, век. В музыке мы сталкиваемся как с линейным, так и с циклическим аспектом восприятия или использования времени. Музыка в основном состоит из трех типов материала. Речь идет о новом, неизвестном, контрастном элементе, который находится в основе линейной структуры. Затем есть элемент повторения уже известного, тождественного, которое составляет основу циклической структуры. И наконец, есть элемент вариации, который представляет собой комбинацию двух предыдущих типов. Повторение основа симметрии музыкальной структуры. Через повторение создаются принцип и форма музыкального произведения. Цель формы - облегчить ориентацию слушателя в музыкальной структуре, а также создать напряжение между ожиданиями слушателя и реальностью (Flašar, 2017).

Построение и переоценка формы музыкального произведения представляет интерес для большинства композиторов. Попытка ввести точную меру внутреннего порядка композиции привела к появлению принципов расположения всех количественно-качественных параметров композиции. Мы называем такую структуру серией. Отсюда и название такой сочиненной музыки - сериализм. Интересно, что сериалистическая музыка (Serielle Musik), в которой музыкальная структура постоянно меняется по всем параметрам (высота, длина, динамика, тон), невозможна с точки зрения слушателя, исходя из психологии восприятия принципов сходства, близости и непрерывности. В результате музыка ускользает от внимания слушателя и его возможности зафиксировать ее в памяти. Сериалистические композиции притязательны, их внутренняя аранжировка сложна и плохо улавливаема, производит на слушателя впечатление хаoсa (Fraňek, 2007).

В ответ на эту сложность предпринимаются попытки упростить или минимизировать формальные требования к созданию композиции. В результате получается минималистичная или репетитивная музыка. Источником репетитивной музыки является сериализм Второй венской школы (Шенберг, Берг, 
Кратохвил, М.: Значение серийности и повторения музыкального и...

ЗБОРНИК РАДОВА • ГОД. 24 • БР. 23 • ДЕЦЕМБАР 2021 • 187-206

Beбер / Schoenberg, Berg, Weber). Один из главных представителей американской минимал-музыки Стив Райх (Steve Reich) тоже изначально обучался додекафонии и сериализму, что не соответствовало его натуре. Работая над своим последним сочинением в Джульярдской школе с Лучано Берле в 1962 году, он адаптировал принципы додекафонии следующим образом: «Приспосабливаясь к стилю, который я никогда не считал совместимым с базовой музыкальной интуицией, [...] я не делал инверсию повторения, транспозицию из другого тона, а просто повторял серию снова и снова. И это было так, как если бы я делал что-то с музыкой, которая мне казалась немузыкальной» (Reich, 1991). Повторяющаяся структура работает как с линейным, так и с циклическим принципом времени. Это сочетание механического повторения и орнаментальной изменчивости. Наглядной аналогией этого принципа могут служить роликовые узоры или трафаретная роспись.

\section{ВЫСТАВОЧНАЯ СЕРИЯ}

На кафедре изобразительного искусства и образования педагогического факультета Университета Константина Философа в Нитре мы применяем различные методы передачи студентам содержания и форм, которые они впоследствии будут применять в своей педагогической практике. Один из них это стратегия подготовки и проведения выставки в помещении Университетской галереи на территории педагогического факультета. У выставок свои традиции и общие форматы. Примерами являются выставки семестровых работ студентов, которые ежегодно проходят под названием «АУДИТ», или выставки дипломных работ под названием «ДИПЛОМ». Другой пример - одиночные выставки, где студенты принимают непосредственное участие в создании и инсталляции экспонатов. Конкретный пример - выставочный проект «PODLAHA», который проходил в зимнем семестре 2019/2020 учебного года. Открытие выставки состоялось 21 ноября 2019 года.

Автор концепции и куратор выставки - автор статьи. Соавторами выставки были студенты 1 и 2 курсов по программе «Учителя изобразительного искусства».

Концепцией выставки было создание пространства для возникновения дискуссии о возможностях интермедиа и междисциплинарных пересечениях художественного творчества. Концепция выставки была разработана таким образом, чтобы студенты при создании выставки могли непосредственно исследовать природу средств выражения не только художественного творчества. Были исследованы отношения отдельных элементов, таких как цвет и пространство, пространство и поверхность, точка, движение точки на плоскости и в пространстве, форма и цвет. В ходе фактической реализации выставочного проекта были раскрыты темы компоновки конструкционных элементов и создания композиции. Были исследованы способы наслоения, 
Кратохвил, М.: Значение серийности и повторения музыкального и... ЗБОРНИК РАДОВА • ГОД. 24 • БР. 23 • ДЕЦЕМБАР 2021 • 187-206

наложения, фазового сдвига, оптической пульсации формы и цветового ритма, повторения художественных элементов. В ходе дискуссий в рамках реализации выставки были обозначены темы по определению построения композиции, влияния материалов на творческий процесс, а также такие проблемы как узор, декор, орнамент, цветовая гармония или цветовой аккорд, контраст, контрапункт, акцент.

\section{ИНСТАЛЛЯЦИЯ}

Выставка была реализована в виде коллективной живописи на полу галереи с помощью шаблонов. Масштаб живописной деятельности занял почти всю площадь галереи, создав впечатляющее пространство (Рис. 1-6).
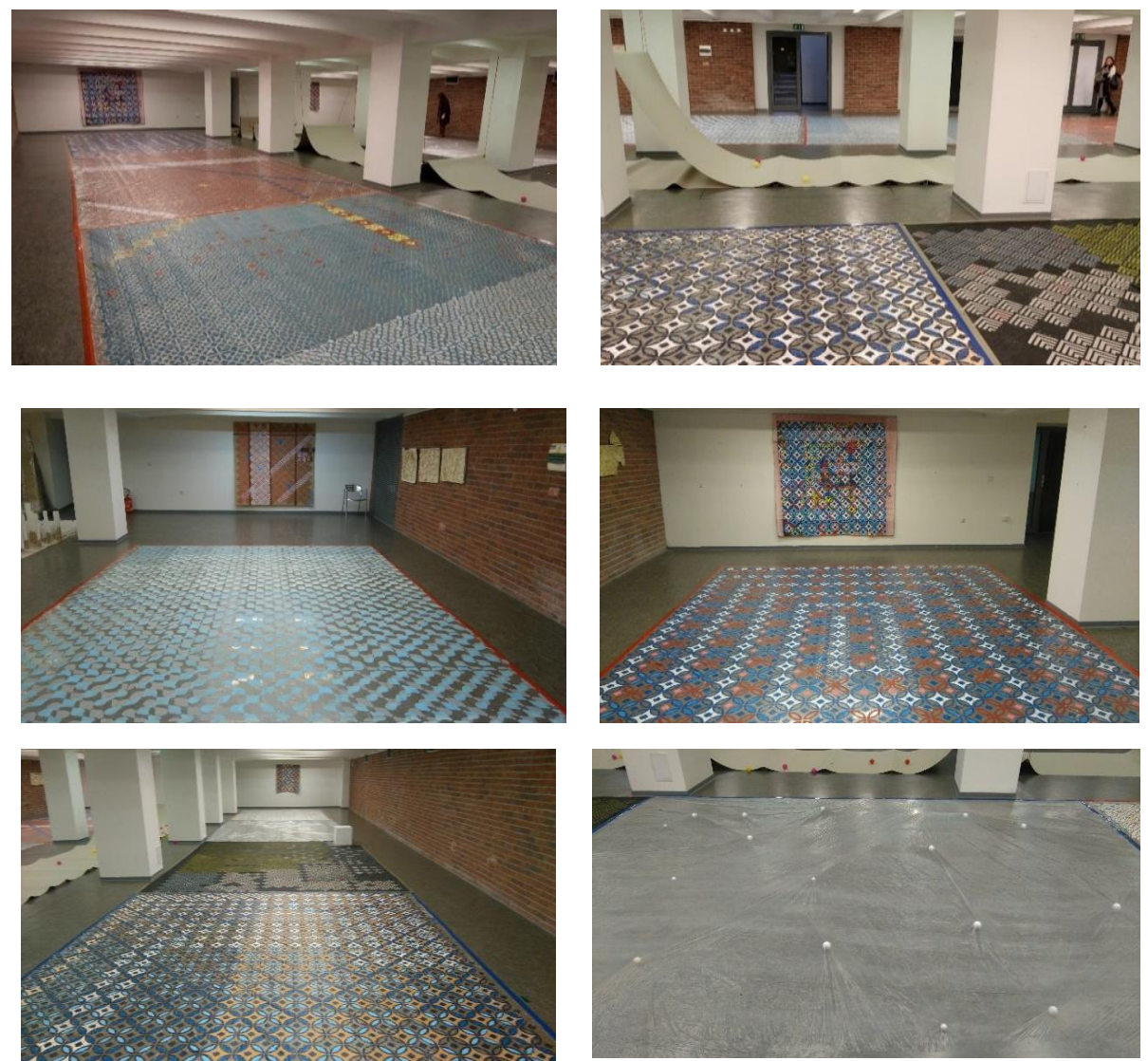

Рис. 1-6 Вид на инсталляциию выставки PODLAHA (источник архив автора) 
Кратохвил, М.: Значение серийности и повторения музыкального и...

ЗБОРНИК РАДОВА • ГОД. 24 • БР. 23 • ДЕЦЕМБАР 2021 • 187-206

В рамках подготовки и отработки технологического процесса были выполнены картины на картоне форматов 2 х 2 м и 1 х 1 м (Рис. 7-8).
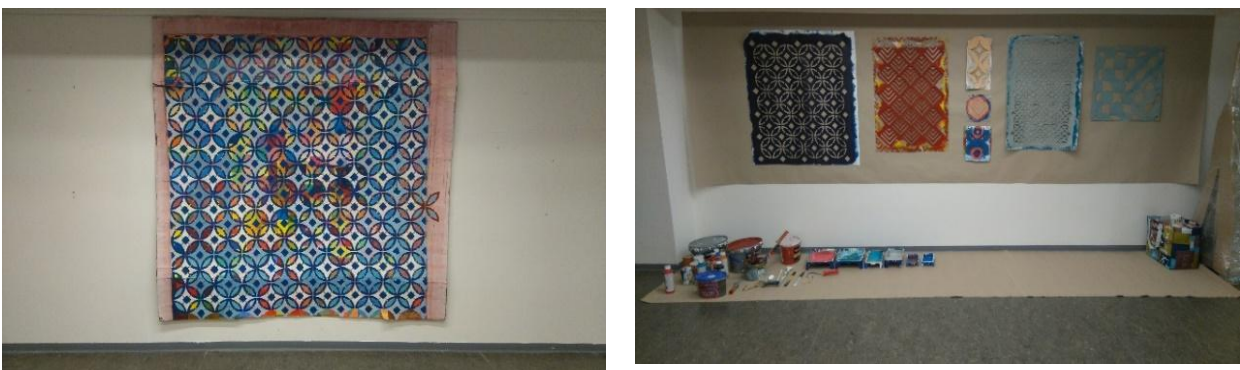

Рис. 7-8 Живопись на картоне размером 2 х 2 м и выставленные инструменты и приспособления (источник архив автора)

Студенты познакомились и овладели техникой росписи через трафарет с помощью валиков, отпечатывания кистями и губками. Для реализации использовались пластиковые шаблоны A1 и А0. Благодаря выставочным условиям университетской галереи не было возможности реализовать замысел рисования прямо на полу. В качестве альтернативы были выбраны напольные покрытия большой площади из черного нетканого материала, покрытые прозрачной пленой HDPE 4,5 мкм и LDPE 35 мкм с размерами 5 х 4 м. Пленка крепились к полу цветной липкой лентой. В галерее образовались 6 зон, каждая площадью $20 \mathrm{~m}^{2}$. Эти зоны составляли единое целое. Сама организация пространства для рисования напоминала поле физкультурного зала. Этот момент побудил участников выставки обсудить междисциплинарные отношения изобразительного искусства и спорта. Результатом дискуссии стала идея завершающей бакалаврской работы на тему «Спорт и изобразительное искусство». Концепция выставки, реализованная на полу, явилась результатом стимулов в создании и реализации пола в частном жилом пространстве, которые были вдохновлены традиционным рисунком цементной плитки. Во время изготовления пола методом закраски по шаблону на цементной стяжке произошло несколько интересных оптико-пространственных явлений (Рис. 21-22).
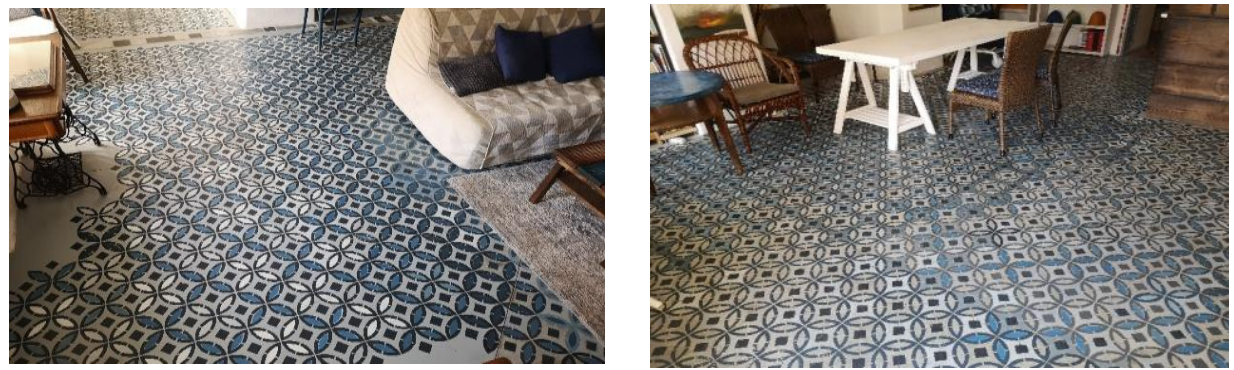

Рис. 21-22 Трафаретная роспись на цементном полу в частных апартаментах (источник архив автора) 
Кратохвил, М.: Значение серийности и повторения музыкального и...

ЗБОРНИК РАДОВА • ГОД. 24 • БР. 23 • ДЕЦЕМБАР 2021 • 187-206

\section{ОПИСАНИЕ И АНАЛИЗ КОМПОЗИЦИОННЫХ СТРУКТУР}

Шаблон со своим рисунком имеет линейный характер и является определяющим фактором базовой структуры расположения всех элементов композиции. Линейный характер шаблона образует абстрактную геометрическую сетку «раскраску». Заполняя эту «раскраску», мы можем делать акценты на различных отдельных элементах основного узора и, таким образом, создавать разные наборы узоров. Мы можем наблюдать линейную взаимосвязь отдельных форм и обращать внимание на их ритмическое (правильное или неправильное) чередование. Сам цвет создает пространственное воздействие на смотрящего. Чередованием светлых и темных или теплых и холодных тонов, создается оптико-пространственная иллюзия. Повторяющийся узор определенного размера на достаточно большой площади также создает оптико-кинетическую иллюзию. Большой размер рисунка на полу, чередование цветовых узоров в повторяющейся и ритмично пространственной иллюзии способствовали возникновению галлюцинаторнокинетико-иллюзорного восприятия. Оно было наиболее интенсивным, особенно когда внимание художника постоянно переключалось с деталей на общий вид всей площади рисунка. Это ощущение усиливалось за счет повторяющейся физической нагрузки от приседаний до стояния и изменения давления в теле. Сочетание и вариативность цветовых схем вызвали обсуждение неисчерпаемых возможностей в рамках закрытой системы, которой является также и живопись. Работа с шаблоном или узорами побуждает задуматься о математических моделях творчества и таких концепциях, как вариации, комбинации, перегруппировки или структурирование художественных элементов с использованием точных правил в повторении или серии.

На выставке использовались четыре типа шаблонов с разным узором. Один узор (рис. 2, 4, 6, 7) использовался на двух противоположных поверхностях. Именно на этом примере можно продемонстрировать вариативность возможных сочетаний и акцентов различных мотивов композиции (Рис. 15-20).
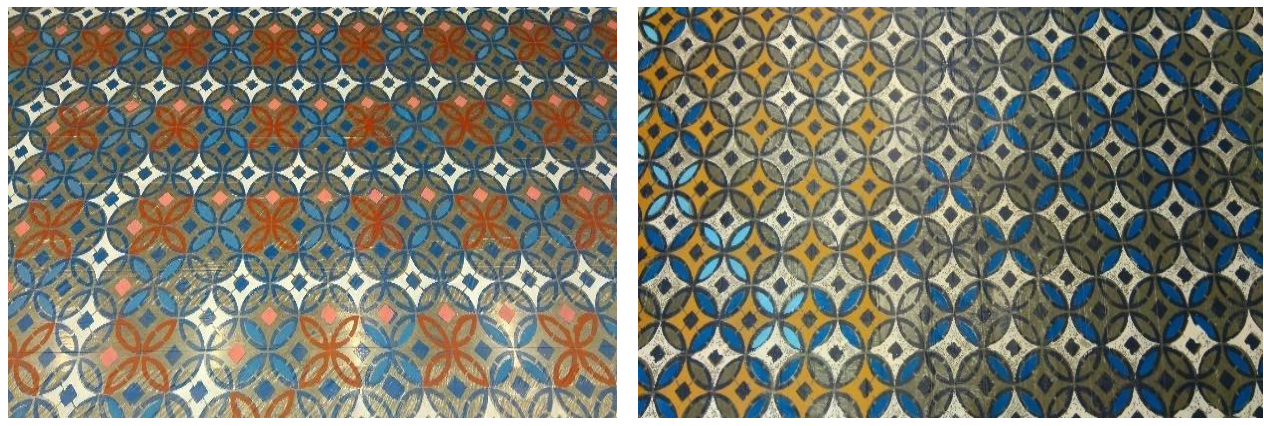
Кратохвил, М.: Значение серийности и повторения музыкального и... ЗБОРНИК РАДОВА • ГОД. 24 • БР. 23 • ДЕЦЕМБАР 2021 • 187-206
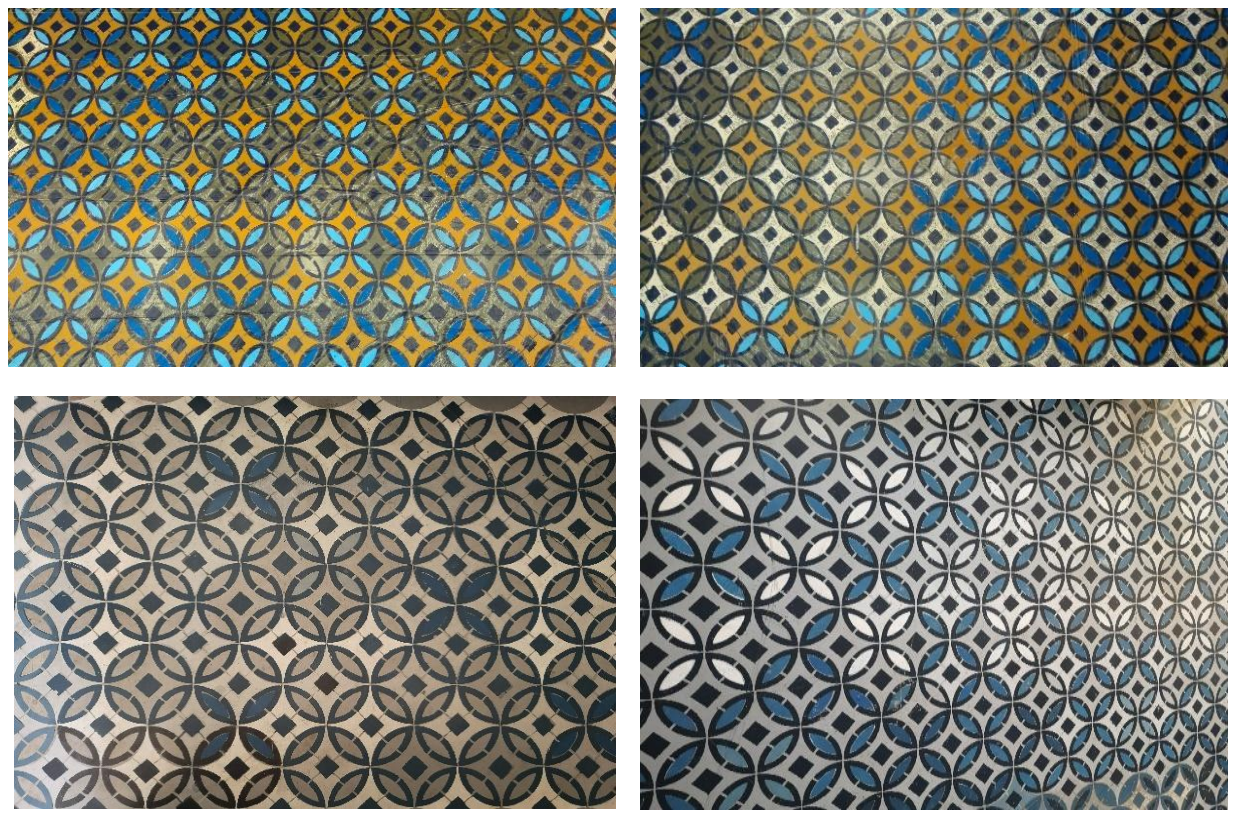

Рис. 15-20 Вариации одного узора (источник архив автора)

Некоторые образцы шаблонов не допускали подхода «раскраски», но позволяли использовать движение и наложение цветных слоев. В одном случае выбор оттенков синего и бирюзового создал эффект водной глади. Этот эффект при определенном угле обзора усиливался и создавал оптическую иллюзию ряби на поверхности (Рис. 12).
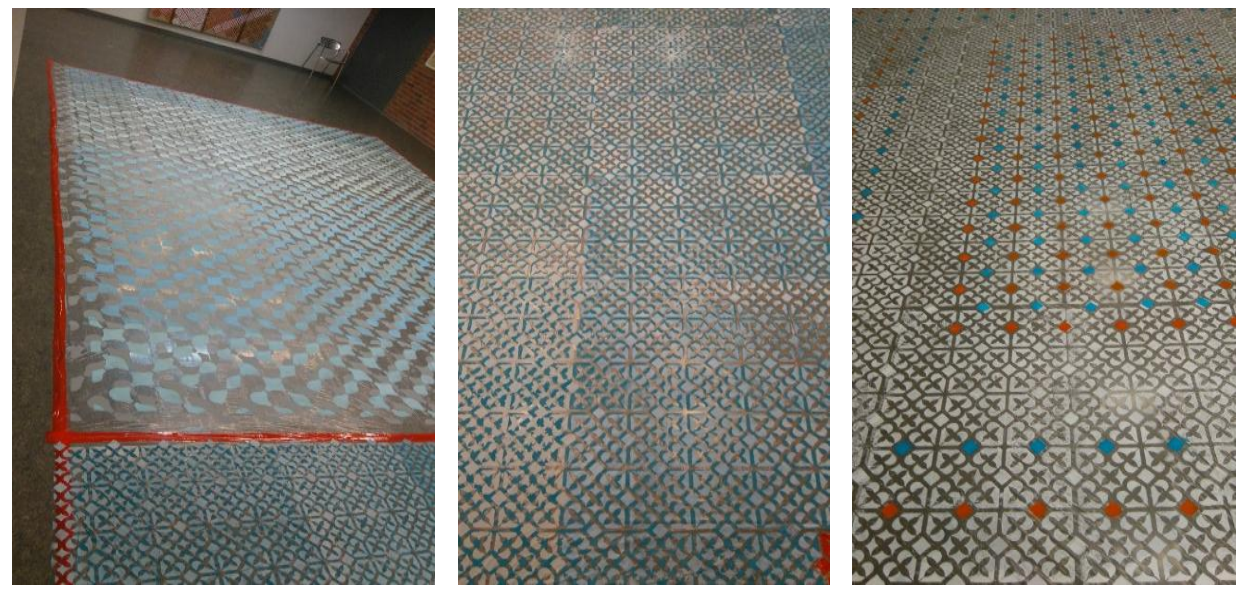

Рис. 12-14 Работа с фазовым сдвигом и перекрытием слоев. Точечные акценты (источник архив автора) 
На одной из поверхностей использовался покрывающий материал прозрачной пленки, под которой размещались белые пенополистирольные шарики разных размеров. В этом поле студенты наблюдали элементарные отношения взаимодействия точек на плоскости и под ней (Рис. 5).

В центре инсталляции, разделившей выставочное пространство на две основные части, были установлены рулоны бумаги и гофрированная бумажная поверхность в пространстве. Здесь были размещены яркие пластиковые шарыиз детских игр. Инсталляция сделала возможной интерактивность: зритель мог бросать шары на наклонную плоскость и наблюдать за фактическим движением точки на поверхности. Цветовой акцент шариков также использовался при установке рулонов бумаги, которые были сгруппированы в одном месте и образовали вертикальную структуру из линий и точек (Рис. 9-11).
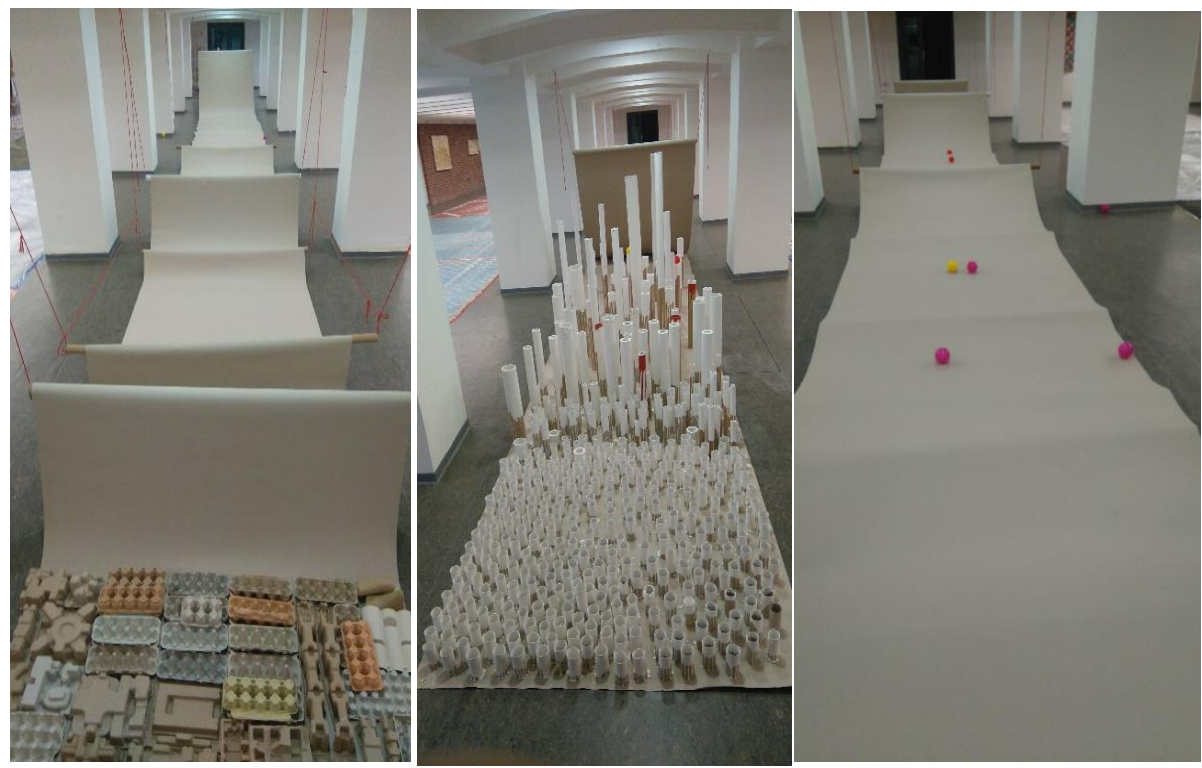

Рис. 9-11 Горизонтально-вертикальные структуры, волнистая поверхность, точки на поверхности (источник архив автора)

Среди экспонатов были и сами трафареты, и художественные принадлежности, и краски. Была предложена также чистая бумажная поверхность, символизирующая открытость и незавершенность реализованности живописных полей, где посетителям предлагали опробовать технику рисования по шаблону. Эти экспонаты раскрыли процесс создания картины на полу (Рис. 8). Выставка была подготовлена как перформативная параллель игр со словом, звуком и образом, а также спортивными и детскими играми с мячиками. Выставку открыла музыкант - исполнитель, которая 
Кратохвил, М.: Значение серийности и повторения музыкального и...

ЗБОРНИК РАДОВА • ГОД. 24 • БР. 23 • ДЕЦЕМБАР 2021 • 187-206

играла обнаженной (nahá). Название выставки изменилось с «PODLAHA» («Пол») на «Рodl'aHА». С помощью игры слов акцентировали внимание на «ha» в выражении «aha» «ha-ha». Во время акустической игры, среди прочего, были реализованы тона и аккорды «Н» и «А».

Программу вернисажа показывали студенты кафедры изобразительного искусства и образования, которые имели музыкальное образование или просто способности к музыке. Исполняя на гитаре авторскую песню, Эмма Кнеблова (Ema Kneblová), акцентировала слова на «Н». Следующим выступлением была интерпретация произведений Яна Тирсена в исполнении студентки Сильвии Новосадовой. Во время экскурсии куратор комментировал, интерпретировал и объяснял конкретные работы и концепцию всей выставки. Он также использовал электронное пианино как средство демонстрации композиционных параллелей и аллюзий выставочной среды, играя композицию Яна Тирсена (Yan Tirsen). В ходе дискуссии обсуждались проблемы музыкальной и художественной формы, гармонии и додекафонии, репетитивности и сериализма. Было выявлено несколько интересных аналогий и параллелей в музыке, искусстве и образовании. Мы приведем несколько из них.

\section{ВИЗУАЛЬНОЕ И АКУСТИЧЕСКОЕ ПРОСТРАНСТВО}

Проблемой пространства и изменением восприятия пространства живописи как процессуального явления занимались еще футуристы, рассматривавшие перформативную презентацию как живописную деятельность.

Начало истории футуристической деятельности относится к 20 февраля 1909 года, когда в крупнейшей парижской ежедневной газете «Le Figaro» был опубликован Первый футуристический манифест. Его автор, итальянец Филиппо Томмазо Маринетти (Filippo Tommaso Marinetti), избрал парижскую публику целью своего взрывного манифеста. Маринетти собрал художников из Милана и его окрестностей и объединил их в деле футуризма, когда 8 марта 1910 года они организовали футуристический вечер в Театре «Кьярелла» в Турине. «Для нас жест - это не просто фиксация момента универсального динамизма. Это определенное динамическое переживание вечности», заявили футуристы. С определенной безотлагательностью «активности» и «изменения» искусства, которое «ищет свои собственные элементы в своем окружении», художники-футуристы обратились к перформансам как к более прямому способу представления своих идей публике. Боччиони заявил, что картины не должны быть просто застывшей сценой или фоном для театральной постановки. Точно так же Соффичи (Soficci) писал, что «зритель должен быть в центре картины». Вот такими и подобными были рекомендации художников - футуристов, которые видели живописную деятельность как перфоманс (Goldberg, 2001). 
Кратохвил, М.: Значение серийности и повторения музыкального и...

ЗБОРНИК РАДОВА • ГОД. 24 • БР. 23 • ДЕЦЕМБАР 2021 • 187-206

Один из представителей музыкального минимализма и, соответственно, репетитивной музыки Ла Монте Янг (La Monte Yang) (1935) в трио Слачика (1958) впервые применил свою концепцию открытия звукового пространства, основанную на долгом звучании тонов (в этом случае несколькоминутное звучание кварт и квинт). «Слушатель должен проникнуть внутрь звука, [...] что становится проще, если тоны очень длинные» (Pudlák, 1991). Таким образом, Янг имеет дело с реальными тонами и так же с такими, которые возникают в воображении слушателя (частичные и аликвотные тоны). В произведении «Тһе Tortoise: His Dreams and Journeys" (1964) основные нижние тоны обрабатываются электронным способом, и отдельные инструменталисты и певцы могут сами решать, какую аликвоту играть или петь. В своей композиции «Drift Studies» (1966) он использовал синусоидальный тон, который слушатель должен «раскрасить» в своем воображении, что создает интересный эффект единения звука и впечатлений. «У вас возникает чудесное ощущение, что ваше тело мягко плывет в пространстве и времени, увлекаемое этими звуковыми волнами» (Dorůžka, 1991). Проведем параллель с выставкой «PODLAHA». Это пространство живописи на полу, в которое зритель мог войти и стать его частью. Размер картины и ее горизонтальное расположение аналогичны длине тонов, поглощающих слушателя. Аликвотные тоны мы могли бы сравнить с возможностью выбора родственного цвета, который создает тень и, таким образом, пространственную иллюзию за счет изменения формы. Изменение цвета и формы также вызывает вибрацию основного цветового тона и создает оптическую иллюзию движения. Установленная волнистая поверхность бумаги на синусоиде соответствует акустическому фону тонов, текущих через пространство.

\section{ИНСТРУКЦИИ И РЕКОМЕНДАЦИИ}

Инструкция «организовывать», сохраняя при этом определенную степень свободы и импровизации, также дана в работе американского композитора Терри Райли (Terry Rieley) (1935). Одна из его самых известных композиций «In C» (1964), которую он создал после возвращения из Европы, состоит из 53 мелодико-ритмических моделей, которые могут быть воспроизведены любым количеством исполнителей на любом инструменте. Каждый исполнитель может выбрать, когда начинать игру и сколько раз повторять модель. Одинаковым есть лишь только темп, этакая пульсация в восьмых значениях. В результате получается музыка равномерной пульсации во множестве канонически переплетающихся мелодико-ритмических моделей. При этом возникают особые мелодические и гармонические трансформации, которые, несмотря на так называемое тональное звучание «In C» имеют более модальный (синхронный) характер (Martináková, 2001). 
Кратохвил, М.: Значение серийности и повторения музыкального и...

ЗБОРНИК РАДОВА • ГОД. 24 • БР. 23 • ДЕЦЕМБАР 2021 • 187-206

Находим сходство в работе с шаблонами, где каждый «художникисполнитель» мог выбирать из предложенных шаблонов. В упомянутом проекте выставки «PODLAHA» было четыре основных и три дополнительных шаблона. Художник имел возможность выбирать из разнообразной палитры цветов, и только он решал, какой цвет выбрать, смешивать ли его для использования при создании базовой структуры, которая задается самим шаблоном. Интересным преимуществом являлась работа с дополнительным шаблоном, предназначенным для заполнения внутренних областей конструкции. Выделение выбранной формы выбранным цветом было исходным входом в предопределенную структуру. Художник-исполнитель выбирал сам с чего начать и сколько раз он будет повторять узор. Также интересно было смешивать и накладывать друг на друга отдельные акценты и их ритмические повторения. Это создавало удивительные ритмические преобразования одного и того же рисунка.

\section{ПРОЦЕССУАЛЬНОСТЬ И ОДНОВРЕМЕННОСТЬ}

Следующим примером может быть провозглашенный футуристами Манифест искусства шумов, раскрывающий значение механической музыки, или Динамическая и синоптическая декларация, в которой изложены правила движений тела (body actions), основанные на отрывистых движениях машинных механизмов и как «геометрическая жестикуляция топологических фигур, синтетически образованных в пространствах кубов, квадратов, спиралей и эллипсов». Часть манифеста Синтетического театра была посвящена объяснению идеи одновременности, которая рождается из импровизации, просветления, интуиции (Goldberg, 2001).

Само движение при рисовании на полу определяется окружающей средой и характером поверхности. От вертикального положения тела до приседания, механической разрисовки поверхности и обратно в вертикальное положение, короткий шаг и снова приседание. Все это указывает на механизацию творческой деятельности. Размышляя о самом акте такой живописи, мы приходим к осознанию того, что сам творческий акт находится в самом начале, перед физическим актом рисования (выбор шаблона, акцента, цветов, места и времени) и посленего (рефлексия, коррекция). Акт рисования при работе с шаблонами - это механическое, но сосредоточенное действие.

Как параллель к футуристическому манифесту приведем работу Стива Райха (Steve Reich) (1936), который в 1968 году сформулировал основы своей композиционной техники в работе «Музыка как постепенный процесс» (Music as a Gradual Process). В ней он описывает суть своей музыки, основанной на процессуальности и постепенной внутренней трансформации. «Не представляю сочинение каk процесс. Но сами музыкальные произведения - да, 
Кратохвил, М.: Значение серийности и повторения музыкального и...

ЗБОРНИК РАДОВА • ГОД. 24 • БР. 23 • ДЕЦЕМБАР 2021 • 187-206

- в буквальном смысле являются процессами. Характерной чертой музыкальных процессов является то, что они обусловливают все детали тонов (звуков) и проходят через все формы одновременно (принцип круга или бесконечности). Мне интересно восприятие процессов. Я хочу услышать процесс, происходящий во время музыки» (Reich, 1968).

Упомянутая процессуальность присутствует на протяжении всего действия выставки «PODLAHA». Для зрителя, оставшегося даже после окончания работы над росписью пола, были оставлены все инструменты в виде отдельных экспонатов (Рис. 8).

\section{ОПЬЯНЯЮЩЕЕ ЭХО}

Идею повторения можно также найти у Филиппо Томмазо Маринетти (Filippo Thommaso Marinetti) (в его работе «Zang tumb tumb», которая была первоначально написана в письме из болгарских окопов художнику Расселу в 1912 году. Маринетти описывает «оркестр большой битвы»: «каждые пять секунд осаждающие пушки рассекали пространство аккордом «там-тумбтуумб», умноженным на пятьсот эхо, пронзая, рубя, рассеивая звук до бесконечности» (Goldberg, 2001).

В творчестве другого американского композитора Филипа Гласса (Philip Glass) (1937) мы находим развитие репетитивного характера композиции. Гласс пришел к новому композиционному выражению, суть которого заключается в принципе повторения коротких мотивов с дополнительными ритмическими значениями и постоянными вариациями, которые через определенное время переходят (как бы перепрыгивая) из одной в другую. Он думал, что слушатель должен воспринимать музыку целостно, без начала и конца, отлично от европейской традиции, на принципе контраста, репризы и постепенной градации. То есть согласно Глассу в наративном аспекте (Martináková, 2001). Интересно также, что эту музыку называют трансовой, гипнотической, процессуальной, модульной, а более провокационно «музыка, идущая в никуда» (going-nowhere music) (Gann, 2015).

\section{ЗАМЕШАТЕЛЬСТВО}

Интересным явлением на выставке PODLAHA стала реакция зрителей и их неуверенность при входе в выставочную среду. Сама инсталляция позволяла зрителю наступать на реализованные картины на полу. Однако зритель был в замешательстве: если он решит обойти, то не приблизится к инсталляции, расположенной в центре выставочного пространства. Обеспокоенность возникла из-за традиционной концепции «не касаться 
Кратохвил, М.: Значение серийности и повторения музыкального и...

ЗБОРНИК РАДОВА • ГОД. 24 • БР. 23 • ДЕЦЕМБАР 2021 • 187-206

экспоната», не говоря уже о том, чтобы наступать на него. Причина неуверенности также могла быть связана с опасениями по поводу состояния собственной обуви.

Сходство неуверенности в восприятии музыкального произведения можно найти в «хаотичных» композициях представителей сериализма (Карлхайнц Штокхаузен (Karlheinz Stockhausen)) или в интерпретации композиции «4 '33'» Джона Кейджа (John Cage).

\section{ИГРИВОСТЬ, ЮМОР, РЕФЛЕКСИЯ}

Подобно тому, как футуристы боролись против литературного, художественного или музыкального консенсуса того времени, вышеупомянутое движение ДАДА и его представители любили играть с серьезностью, юмором и тривиальностью. Словесные игры как часть музыкального мира в настоящее время встречаются, например, в творчестве русско-словацкого композитора и пианиста Евгения Иршая. Названия некоторых его композиций или музыкальных альбомов имеют игривый или юмористический характер.«MILANOLO CONCERTOS», «SAX-O-PHUN», «Bassome mucho», «Huslehubky» или «Pimpampunči» - это названия, которые демонстрируют юмористическое измерение в серьезном и самобытном композиционном выражении автора. В нашем контексте необходимо упомянуть его размышления о творчестве Арнольда Шёнберга в проекте «Schoenberg variations», а также размышления о творчестве Филиппа Гласса (Philip Glass) в композиции «A Glass of Glass». Как пишет Петр Катина (Peter Katina) в сопроводительном тексте к компакт-диску «А Glass of Glass», речь идет о полном консенсусе Иршая не только с музыкой Филиппа Гласса, но и с жанром минимализма как таковым. Хотя композиция использует элементарные приемы минимализма, мотивы в ней представляют характерные композиционные элементы Иршая: сильная мелодия, сильный и богатоструктурированный ритм, юмор и чувство игры с контекстными наложениями «вне холста». Композиция состоит из мозаики взаимно контрастирующих частей, которые постоянно звучат в слегка измененном виде. Важным элементом является очень подвижный материал в форме звучащей прелюдии Шостаковича, сочетающей маршевые, милитаристские элементы с юмористическим восходящим и нисходящим движением в сжатый, симфонически звучащий музыкальный образ, полный иронии. Особый эпизод - это раздел, наполненный джазовыми ритмами с попеременно звучащими акцентами, напоминающими искусственные ритмы игровых автоматов и механических игрушек. Музыка стабильно движется в тонком динамическом диапазоне от «пиано» до «меццофорте», и только в конце произведения появляется долгожданная изюминка - торжественное звучание домажоровых секвенций. Игра слов в названии не врет, «стакан», 
Кратохвил, М.: Значение серийности и повторения музыкального и...

ЗБОРНИК РАДОВА • ГОД. 24 • БР. 23 • ДЕЦЕМБАР 2021 • 187-206

вдохновленный Глассом на качественную музыку, дополняется Иршаем сполна (Katina, 2020).

Сама выставка была развлекательным мероприятием, в котором был создан ряд веселых моментов (уже упомянутые игры со словом PODLAHA или игровая активность с цветными шариками). Некоторые моменты становились веселыми не сразу, потому что в изначально они были трагикомическими. Например, спотыкание о пластиковый пол в результате которого банка с краской выливалась или непроизвольное смешивание синтетической краски с водой. Интересным также был демонтаж выставки, в ходе которого было обнаружено, что часть нетканого материала прилипла к полу, и необходимо было механически (с помощью шпателей) очистить $20 \mathrm{~m}^{2}$ пола. И тут возникло идеальное время и место для рефлексии и обсуждения проблем творчества и его презентации.

Процесс реализации выставки в галерее представляет собой комплексную интерактивную деятельность, которая интенсивно способствует развитию художественно-педагогических навыков и опыта не только студентов, но и их педагогов. Можно и далее проводить аналогии между музыкальными, изобразительными произведениями минималистов и нашей работой. Назовем и другие имена авторов, чьи произведения могут быть упомянуты при анализе вопросов серии, повторения, рисунка и ритма в искусстве. Такие музыканты, как Эрик Сати, Морис Равель, Джон Адамс, Майкл Найман, Хенрик Гурецкий и Арво Пярт, (Erik Satie, Mauricie Ravel, John Adams, Michael Nyman, Henryk Górecki, Arvo Pärt), а также художники М. К. Эшер, Энди Уорхол, Джаспер Джонс, Джексон Поллок, Пауль Клее, Виктор Вазарели, Хесус-Рафаэль Сото, Милан Добеш (M.C. Escher, Andy Warhol, Jasper Johns, Jackson Pollock, Paul Klee, Victor Vaserely, Jesús-Rafael Soto, Milan Dobeš) и многие другие.

\section{ЗАКЛЮЧЕНИЕ}

На кафедре изобразительного искусства и образования мы ищем верное соотношение между традиционными и современными, циклическими и линейными методами подготовки студентов к их будущей профессии. Это и есть поиск баланса между повторением уже известного и рефлексией к настоящему. Сам метод передачи информации также имеет последовательный и повторяющийся характер. Его структура основана на порядке выполнения отдельных этапов решения проблемных задач. Сначала практика, приобретение опыта, совместное проведение мероприятия (например, реализация выставки «PODLAHA»). Далее следует рефлексия и попытка идентифицировать наиболее значимое или профессиональные проблемы (анализ и обсуждение на семинарах). На следующем этапе мы анализируем эти 
Кратохвил, М.: Значение серийности и повторения музыкального и...

ЗБОРНИК РАДОВА • ГОД. 24 • БР. 23 • ДЕЦЕМБАР 2021 • 187-206

явления или проблемы с точки зрения студенческого коллектива, сравниваем их с существующими знаниями (лекции, выполнение семинарских заданий, итоговых работ). Заключительный этап - это снова практическая реализация проблемы в форме устного высказывания или художественно-педагогического мероприятия (самостоятельная художественная деятельность или педагогическая практика). Таким образом эта последняя фаза фактически снова становится первой фазой процесса. Это движение по кругу, а точнее по спирали, и есть сутью циклически-линейной методикой. Преимущество этой методики заключается в ее сложности, которая находит свое отражение в личной заинтересованности и вовлеченности участников в процесс. Этотпроцесс аналогичен повторяющемуся ритму обучения, художественной деятельности и педагогической работы.

Композиционные приемы, основанные на повторении определенного рисунка, определяют внешнюю ритмическую структуру произведения. Эта структура, если она достаточно открыта для внутренних изменений, позволяет реализовать ряд композиций, которые могут выступать как части целого или как отдельные единицы. Вариативность повторяющихся и образцовых приемов построения композиции позволяет развивать комбинаторное или рациональное мышление. Степень добавления или удаления отдельных элементов, в свою очередь, развивает интуитивный опыт рисования. Таким образом мы хотим построить новое отношение к повторению как к серии возможных бесконечных вариаций творческого процесса.

Феномен повторения или копирования присущ некоторым медиа и является их неотъемлемой частью. Для графики и фотографии принцип повторения и воспроизведения - это сам способ существования. Свое воплощение, основанное на технике дублирования и воспроизведения, находит и повторение в цифровых медиа.

Явление повторения в некотором смысле также выражается во многих лингвистических формах, которые реализуют значения серии или повторения чего-либо. Такие термины, как: рекурренция, итерация, избыточность, хроничность, рецидив, репетиция, остинато, эхо, эхокинез, эхоматизм, эхолалия, палиллярный, катапазис, вербигерация, аллитерация, эпифора, эпизеукса, аугментация, анадиплез и др. выражают разные нюансы исследуемых проблем в разных сферах жизни. Некоторые из них относятся к художественным, другие к патологическим проявлениям. Таким образом повторение - это основной принцип жизни, который представляет собой колебание между прошлым и будущим. Степень точности, скорости, сложности, изменчивости, подлинности или количества ошибок повторения определяет целенаправленность и значимость этого принципа. 


\section{Библиографические ссылки}

Dorůžka, P. (1991). Hudba na pomezí. Praha: Panton.

Flašar, M. (2017). Minimal music ako problém figúry a pozadia. In Z. Rusínová (ed.): Serialita a repetícia ako tvorivé princípy integrovaného umeleckého diela (41-62). Bratislava: VŠVU.

Fraňek, M. (2007). Hudební psychologie. Praha: Karolinum.

Goldberg, R. (2001). Performance Art. London: Thames \& Hudson Ltd.

Gann, K. (2015). Nevd'ačné pokusy o definíciu minimalizmu. Hudobný život, XXXIII(7-8), 48-56.

Katina, P. (2020). A Glass Of Glass Hudba Jevgenija Iršaia pre dva klavíry. In J. Iršai A Glass Of Glass, Booklet CD.

Králik, L. (2015). Stručný etymologický slovník slovenčiny. Bratislava: VEDA.

Martináková, Z. (2001). Minimal - art a minimal - music - opakujúca sa tendencia v umení?. Hudobný život, XXXIII(10), 33-36.

Pudlák, M. (1991). Minimalismus a čas v hudbe. Slovenská hudba, 2-3, 188-199.

Reich, S. (1968). Music as a Gradual Process. Retrieved September 20, 2020 from the World Wide Web http://www.bussigel.com/systemsforplay/wpcontent/uploads/2014/02/Reich_Gradual-Process.pdf.

Reich, S. (1991). Myšlienky. Slovenská hudba, 2-3, 183-184.

Rusínová, Z. (2017). Serialita a repetícia ako príbuzné aspekty umenia, vedy a života. In Z. Rusínová (ed.): Serialita a repetícia ako tvorivé princípy integrovaného umeleckého diela (12-25). Bratislava: VŠVU.

Valoch, J. (2000). Dílo Miloše Urbáska. Retrieved October 19, 2020 from the World Wide Web http://urbasek.com/index-cs.html a http://urbasek.com/jiri-valoch-dilomilose-urbaska.pdf. 
Кратохвил, М.: Значение серийности и повторения музыкального и... ЗБОРНИК РАДОВА • ГОД. 24 • БР. 23 • ДЕЦЕМБАР 2021 • 187-206

\section{Мартин Кратохвил}

ПФ УКФ, Нитра, Словачка

\section{ВРЕДНОСТ СЕРИЈАЛНОГ И ПОНАВЉАЊА МУЗИЧКОГ И УМЕТНИЧКОГ ИЗРАЖАВАЫА У ПЕДАГОШКОМ ОКРУЖЕЊУ}

\section{Резиме}

Чланак одражава неке аспекте понављања у музичкој и визуелној уметности. У позадини припреме и стварања изложбе уметничких дела ученика наставног програма „Наставник ликовне уметности”, аутор анализира аспекте креативности, у којима се понављање користи као основни принцип. Рефлексије указују на интердисциплинарну интеракцију визуелне и музичке креативности.

Кључне речи: серија, понављање, образаи, ритам, образаи. 